and we grow $2 \frac{1}{2}$ times as much wheat per acre as in the United States or Canada. We are highly mechanized and in many cases our costs compare well with what we have to import. Both soil and climate are in our favour and our workers are good. The root of our trouble is the national unwillingness to realize that this is no 'crisis' with which we are faced, but a long-term, if not permanent, change. Not until this is completely accepted will the requisite national energy be put behind our agricultural drive. Labour, houses, machinery, fertilizers and feeding stuffs are our immediate needs. But they are only the beginning. Whatever our shortages and difficulties may be, the countryside must be re-equipped with new buildings, houses, electricity, water and transport. We need the best that science can give, and we are gradually drawing into agricultural research some of the best brains that science can produce. But we need more ; in fact, if the land of Great Britain is to yield of its best, it will demand a greater share of every section of our national wealth, its energies, capital, income, raw material and, above all, its brains.

Even so, it will take time to achieve the necessary increased production, and when we have achieved it, we shall not have solved the whole problem of feeding the 45 million people who inhabit Great Britain. Neither agriculture nor any other single industry can provide a panacea. In fact, one of the greater lessons that this generation will have to learn from the coming hard times is to give up this passionate belief that panaceas exist. But granted the readiness of the nation to change, and change fundamentally, its whole attitude to agriculture, there is no other industry in the country that can make as great a contribution-long-term contribution - to the future of Great Britain.

\section{PATHOLOGY OF GLASSHOUSE CROPS}

$\mathrm{T}$ HE thirty-first annual report for 1945 of the Cheshunt Experimental and Research Station (Turner's Hill, Cheshunt, Herts, 1946) sets forth the results of several pieces of research into the pathology of glasshouse crops.

P. H. Williams has investigated the effect of tem. perature and humidity on the pathogenicity of Verticillium albo-atrum and V. dahlioe. He finds that $V$. albo-atrum made very little progress when inoculated to tomato plants growing in a closed chamber, with temperature and humidity higher than normal. The plants did not wilt in this environment. $V$. dahlice, on the other hand, caused about the same amount of disease in a closed chamber and under normal conditions. Verticillium wilts do not appear to owe greater severity of attack to increasing soil moisture. Cucumber plants wilted under con. ditions which checked the disease due to $V$. alboatrum in tomatoes.

The fungus Didymella lycopersici causes a severe stem rot of tomato plants. Mrs. Enid Sheard has shown that the disease can spread by air-borne spores, that an attack is more severe where plants are grown in soil which has been steam-sterilized before inoculation than in unsterilized soil, and that the fungal strain which attacks only the fruit of outdoor tomatoes will not cause stem rot under glass. With O. B. Orchard, Mrs. Sheard has found that aerial infection is controlled by fumigation with formaldehyde vapour. W. H. Read has also attempted control of the disease by applying various fungicides to the surface soil of glasshouses, before and during planting.

I. W. Selman has found that fruiting tomato plants may show marked resistance to invasion by mosaic virus, and that inorganic nutrition also has an effect in promoting resistance to mosaic. Experiments are in hand to determine the nutrient balance most favourable to resistance. An interesting application for disease control by antibiotics is investigated by Erma Grossbard. A strain of Aspergillus clavatus has been used to depress the incidence of 'damping off' of tomato seedlings by the fungus Phytophthora cryptogea. Antibiotic properties were also demon. strated against Bacillus carotovorus. Further trials with petroleum emulsion for the control of red spider mite have been made by E. R. Speyer and W. J. Parr. Large-scale use of D.D.T. has proved of value against the tomato moth, but applications of sodium ethyl xanthate against root-knot eelworm have not provided much hope of commercial control.

Several non-pathological investigations have also been made. They include the Station's continued work on general cultivation, an evaluation of the use of sulphur and sulphuric acid for making alkaline soils more acid, the choice of extractants in soil analysis, and the effect of plant hormones on the setting of tomato fruit.

\section{FORTHCOMING EVENTS}

Wednesday, December 31

ROYAI MICROSCOPICAL SOCIETY, SECTION OF INDCETRIAL MIOROScopY (in the Hastings Hall, B.M.A. House, Tavistock Square, London, W.C.1), at 5.30 p.m.-Mr. F. D. Armitage : "Microscopy of Paper".

\section{APPOINTMENTS VACANT}

Appuications are invited for the following appointments on or before the dates mentioned:

ENGINEER IN THE AODIO FREQURNCY SECTION of the Research Department, based in London, ENGINEERS (2) IN THE FIELD STRENGTH SHCTION of the Research Department, based at Oxford, ENGINkRRS (senior and junior) IN THE DESIGNS DEPARTMENT in London-The Engineering Fstablishment Officer, B.B.C., Broadcasting House, condon, W.1 (January 3)

Assistant Chemists (2) IN THe Chemistry BRANCh of the Department of Agriculture and Lands, Southern Rhodesia-The Office of the High Commissioner for Southern Rhodesia, 429 Strand, London, W.C.2 (January 5)

SUPERINTENDENT IN THE SHIP DIVISION of the National Physical Laboratory in the Department of Scientific and Industrial ResearchThe Secretary, Civil Service Commission, Scientifle Branch, 27 Grosvenor Square, London, W.1, quoting No. 2065 (January 7).

RANKIN LECTORER (Grade I) IN THE PREHISTORIO ARCHAOLOGY of WESTERN EUROPE, and a CHARLES W. JONES LECTURER (Grade II) IN THE DEPARTMENT OF ANGIENT HISTORY AND CLASSIOAL AROH EOLOGY -The Registrar, The University, Liverpool (January 8)

LECTURER IN ELEOTRONICS in the University of Adelaide-The Secretary, Universities Bureau of the British Empire, 8 Park Street, London, W.1 (January 12).

PRINCIPAL SCIENTIFIo OFFICER at the Royal Air Force Institute of Aviation Medicine, Farnborough, Hants, under the Air MinistryThe Secretary, Civil Service Commission, Scientific Branch, 27 Grosvenor Square, London, W.1, quoting No. 2071 (January 12). CHIEF CONSERVATION OFFICER in charge of the Conservation Branch of the Irrigation Department, Southern Rhodesia-Office of the High Commissioner for Southern Rhodesia, 429 Strand, London, W.C.2 (January 21).

DIREcror of Múseurs-The Town Clerk, Municipal Buildings, Dale Street, Liverpool 2, endorsed 'Director of Museums' (January 26), CHEMIST for an investigation of the isolation and analysis of the insecticidal constituents of pyrethrum flowers-Dr. S. H. Harper. Chemistry Department, King's College, Strand, London, W.C.2 (January 31 ).

HEAD OF THE DhPARTMENT OF PHysios (Senjor Lecturer)-The Secretary, St. Mary's Hospital Medical School, Paddington, London, W.2 (January 31 ).

DIREOTOR-The Director, National Museum of Wales, Cardiff (February 28).

LWOTURER IN THE DEPARTMENT OF ELECTRICAL ENGINEERING AND PHYSICS-The Principal, Borough Polytechnic, Borough Road,
London, S.E.1. 